DOI https://doi.org/10.30929/2307-9770.2019.07.03.07

UDC 378.147:[37.011.3-051:57]:004

\title{
Professional training of a future biology teacher using M-learning technology
}

\author{
Pererva V. V.* \\ Kryvyi Rih State Pedagogical University, Kryvyi Rih, Ukraine
}

Received: $02.08 .2019 \quad$ Accepted: 21.08 .2019

\begin{abstract}
The article is defined the essence of mobile learning, its opportunities in the professional training of a future biology teacher, and outlines its advantages and disadvantages. Implementation of M-learning in the educational process of training future specialists in higher education is in three directions: access to sites with educational information (distance learning); playback of audio, text videos and image files with educational information (refinement, visualization); organization of training using electronic textbooks, training courses and specialized training information files. Organization M-learning is possible using of mobile applications - special applications for mobile phones with educational and developmental function. Representative analysis and practice testing of a various of mobile applications on the Google Play Portal revealed the possibility of using a number of mobile applications in training activities with biology students. Its can be useful in studying the species plants composition, mastering Latin terms, studying the features of practical use of plants, etc. Mobile applications for determining the plant species are represented by a large group of applications, its principle is the analysis of photos of the vegetative and generative parts of the plant and comparing them with the photobase. Some annexes offer expert advice. The reference Mobile applications can be useful in conducting the morphological description of plants, identifying the characteristics of their chemical composition and use in medicine, conducting business activity (crop production). Mobile applications of mastering biological Latin terms can be useful in mastering the disciplines of a professional training cycle. Mobile applications in chemistry can be useful in the study the chemical composition of cells, the course of metabolic processes of aerobes and anaerobes. Basic advantages and lacks of application of mobile studies are certain. M-learning is characterized by mobility and flexibility, appropriate for both classroom and non-classroom forms of student work.
\end{abstract}

Key words: mobile education, M-learning, mobile application, professional training, future biology teacher.

\section{Фахова підготовка майбутнього вчителя біології з використанням технології M-learning}

\author{
Перерва В. В. \\ Криворізький державний педагогічний університет, Кривий Ріг, Україна
}

\begin{abstract}
Анотація. Стаття присвячена розгляду можливостей мобільного навчання (M-learning) як однієї з активних форм електронного навчання (E-learning). Останніми роками вчені все частіше говорять про навчання за допомогою мобільних пристроїв або мобільне навчання. У статті визначена сутність мобільного навчання, його можливості у фаховій підготовці майбутнього вчителя біології. Впровадження M-learning у навчальних процес підготовки майбутніх фахівців у вищій школі відбувається у трьох напрямках: доступу до сайтів 3 навчальною інсрормацією (дистанційне навчання); відтворення звукових, текстових, відео та графічних файлів 3 навчальною інфоормацією (унаочнення, візуалізація); організація навчання з використанням електронних підручників, навчальних курсів і спеціалізованих файлів з навчальною інформацією. Організація M-learning можлива із застосуванням мобільних додатків - спеціальних програм для мобільних телефонів, які мають навчальну та розвивальну функцію. Аналіз представленості та перевірка на практиці ряд мобільних додатків порталу Google Play виявив можливість застосування ряду мобільних додатків під час організації навчальної діяльності зі студентами-біологами. Вони можуть бути корисними при вивченні видового складу рослин, опанування латинських термінів, вивчення особливостей практичного використання рослин та ін. Мобільні додатки з визначення видової приналежності рослин представлені великою групою додатків, принцип роботи яких базується на аналізі фото основних вегетативних та генеративних частин рослини і порівнянні їх з фотобазою. В деяких додатках наявна можливість консультації експертів. Мобільні додатки довідкового характеру можуть бути корисними при проведенні морфологічного опису рослин, виявленні особливостей їх
\end{abstract}

Corresponding Author: Pererva Victoria Victorivna. Phone: +38(097)512-98-91. E-mail: pererva@kdpu.edu.ua Kryvyi Rih State Pedagogical University. Gagaryn Avenue, 54, Kryvyi Rih, Ukraine, 50086.

Відповідальний автор: Перерва Вікторія Вікторівна. Тел: +38(097)512-98-91. E-mail: pererva@kdpu.edu.ua Криворізький державний педагогічний університет, проспект Гагаріна, 54, м. Кривий Ріг, Україна, 50086. 
хімічного складу та використанні у медицині, веденні господарської діяльності (рослинництво). Мобільні додатки можуть бути корисні в опануванні біологічних термінів латинського походження при опануванні навчальних дисциплін циклу фахової підготовки. Мобільні додатки з хімії стануть у нагоді під час вивчення та закріплення знань з хімічного складу клітин, перебігу метаболічних процесів в організмі аеробів та анаеробів тощо. Визначено основні переваги та недоліки застосування мобільного навчання. Технологія M-learning відрізняється мобільністю та гнучкістю, створює умови для зростання продуктивності навчання, доцільна для аудиторних так і позааудиторних форм роботи зі студентами.

Ключові слова: мобільне навчання, M-learning, мобільний додаток, фахова підготовка, майбутній вчитель біології.

\title{
Профессиональная подготовка будущего учителя биологии с использованием технологии M-learning
}

\author{
Перерва В. В. \\ Криворожский государственный педагогический университет, Кривой Рог, Украина
}

\begin{abstract}
Аннотация. Статья посвящена рассмотрению возможностей мобильного обучения (M-learning) как одной из активных форм электронного обучения (E-learning). В последние годы ученые все чаще говорят про обучение с помощью мобильных устройств - мобильное обучение. В статье определена сущность мобильного обучения, его возможности в профессиональной подготовке будущего учителя биологии. Внедрение Мlearning в учебный процесс подготовки будущих специалистов в высшей школе происходит в трех направлениях: доступа к сайтам с учебной инфрормацией (дистанционное обучение); воспроизведение звуковых, текстовых, видео и графических файлов с учебной информацией (наглядность, визуализация); организация обучения с использованием электронных учебников, учебных курсов и специальных фрайлов с учебной информацией. Организация M-learning возможна с использованием мобильных приложений специальных программ для мобильных телефонов, которые имеют обучающую та развивающую ффункцию. Анализ представленности и проверка на практике ряда мобильных приложений портала Google Play выявил возможность использования ряда мобильных приложений во время организации учебной деятельности со студентами-биологами. Они могут быть полезными при изучении видового состава растений, овладения латинскими терминами, изучении особенностей практического использования растений и др. Мобильные приложения по определению видовой принадлежности растений представлены большой группой приложений, принцип работы которых основывается на анализе фоото основных вегетативных и генеративных частей растений и сравнений с фотобазой. В некоторых приложениях есть возможность консультации экспертов. Мобильные приложения справочного характера могут быть полезными при составлении морфологического описания растений, определения специфики их химического состава и использования в медицине, ведении хозяйственной деятельности (растениеводство). Мобильные приложения могут быть полезными при изучении учебных дисциплин цикла профессиональной подготовки. Мобильные приложения по химии могут быть полезными при изучении и закреплении знаний по химическому составу клеток, метаболических процессов в организме аэробов и анаэробов. Выявлены основные преимущества и недостатки использования мобильного обучения. Технология M-learning характеризуется мобильностью и гибкостью, создает условия для улучшения продуктивности обучения, целесообразна для аудиторных и внеаудиторных форм работы со студентами.
\end{abstract}

Ключевые слова: мобильное обучение, M-learning, мобильное приложение, профессиональная подготовка, будущий учитель биологии.

\section{Bcmyn}

Сучасний розвиток інформаційно-комунікаційних технологій (ІКТ) розкриває широкі можливості використання мережі Інтернет в освітній галузі. Застосування Інтернет-технології започаткувало нову форму навчального процесу, яка отримала назву - електронне навчання (E-learning). Найбільшого поширення ця форма набула в галузі вищої освіти. E-learning покладено в основу дистанційного навчання, яке динамічно розвивається, використовуючи різноманітні спеціальні програмноінструментальні платформи [1].

Однією з активних форм E-learning $є$ мобільне навчання (M-learning), яке все більше набуває популярності серед сучасної молоді. M-learning набуває поширення завдяки розвитку технології мобільного зв'язку, що базується на застосуванні мережі Інтернет, і у майбутньому може стати потужним засобом підвищення успішності навчання на всіх етапах становлення особистості - від загальноосвітньої до вищої освіти [2]. 
M-learning (мобільне навчання) співвідноситься з дистанційним та електронним навчанням (Elearning) (рис.1). Спільними рисами мобільного та електронного навчання $є$ використання «мобільних пристроїв» і бездротових мереж. А мобільного та дистанційного навчання - можливість здійснення у будь-який час та будь-якому місці, причому в навчальному процесі обов'язково має місце взаємодія викладача і суб'єкта навчання. Деякі дослідники ототожнюють поняття дистанційне та електронне навчання як взаємозалежні. У такому випадку мобільне навчання можна вважати одним з підвидів еleaning або дистанційного навчання [3]. У порівнянні з електронним та дистанційним навчанням мобільне надає суб'єкту навчання більшу кількість «ступенів вільності» - вищу інтерактивність, більшу свободу руху, більшу кількість технічних засобів [4].

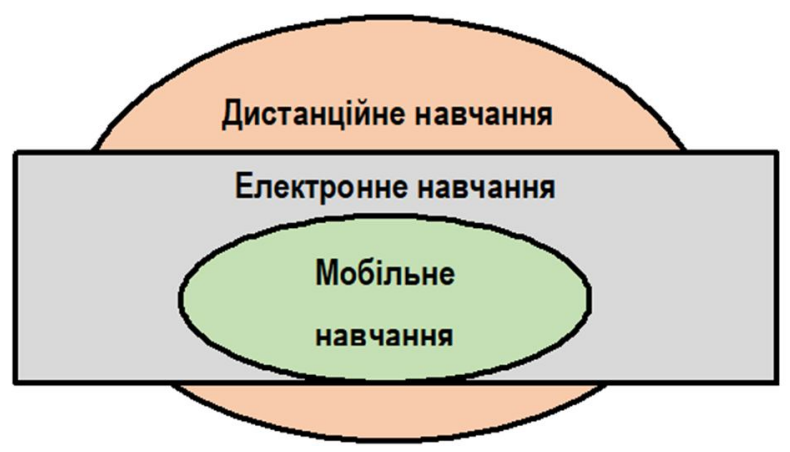

Рис. 1. Співвідношення електронного, дистанційного та мобільного навчання [4]

Велика кількість робіт щодо специфіки застосування мобільного навчання стосується вивчення іноземних мов, проблема ж застосування технології M-learning при вивченні дисциплін циклу фахової підготовки студентів-біологів педагогічними ЗВО не є дослідженою.

Метою публікації є дослідження сутності мобільного навчання, його дидактичних можливостей, напрямів застосування в навчальному процесі фахової підготовки майбутніх вчителів біології.

\section{II Матеріали і методи дослідження}

У наукових дослідженнях останніх років теоретичні та практичні аспекти мобільного навчання розв'язують такі вітчизняні та зарубіжні науковці, як Д.Гікас, М. Грант, В. Кухаренко, Б. Клімова, С. Литвинова, Л. Педро, Н Рашевська, С. Семеріков, Р.Шен та інші [5]. Б. Клімова зауважує, що методика M-learning використовується вже понад 20 років, акцентує на доступності у будь-який час та у будь-якому місці [6].

Мобільне навчання, раніше визначалося як навчання за допомогою мобільних пристроїв, зараз же воно стосується будь-якого типу навчання «на ходу» (learning-on-the-go) або навчання, що використовує переваги мобільних технологій. Це нове визначення зміщує увагу з мобільності технологій на мобільність того, хто навчається. Еволюцію M-learning можна зобразити схемою, наведеною на рис. 2 (за Pachler N., Bachmair B., Cook J., 2010) [7, 8]:

\begin{tabular}{|c|c|c|}
\hline $\begin{array}{c}\text { І ФАЗА } \\
\text { Фокус на пристроях }\end{array}$ & $\begin{array}{c}\text { ॥ ФАЗА } \\
\text { Фокус на навчання поза класом }\end{array}$ & $\begin{array}{c}\text { III ФАЗА } \\
\text { Фокус на мобільності учня }\end{array}$ \\
\hline
\end{tabular}

Рис. 2. Еволюція M-learning

M-learning тісно пов'язана з електронним навчанням, але відрізняється новизною та функціональністю та забезпечує мобільність учня та навчальний потенціал неформальних умов $[9,10]$.

Перевагою мобільності учня $€$ збільшення його незалежності у використанні особистих чи суспільних технологій, що забезпечує набуття нових знань, умінь та досвіду [11]. Р. Шен зауважує, що мобільне навчання здатне подолати певні обмеження: нерозвинутість інфраструктури, бідність, відстань чи розрідженість населення, тому є особливо актуальним для країн, що розвиваються. Тобто технології 
та методи M-learning $€$ не лише інструментом, а новим контекстом навчання [11]. Мобільні пристрої пропонують різні способи навчання, спілкування та спільної роботи [12].

Мобільність розуміється не тільки як фізичний рух, а включає такі концепції мобільності [13]:

1. Фізична мобільність учнів/студентів: свобода вибору часу та місця для навчання.

2. Технологічна мобільність: мобільні пристрої портативні та компактні, можуть бути взаємозамінні залежно від контексту та потреб.

3. Мобільність в концептуальному просторі: навчальні теми «змагаються» за кожного учня. Щоденні ситуації можуть мати навчальне значення, увага ж розподіляється між ними залежно від інтересів, вподобань чи індивідуальних обставин.

4. Соціальна / інтерактивна мобільність: навчання здійснюється на різних рівнях, у різному темпі, у різних соціальних групах, в родині, на робочому місці в умовах множинності взаємодій у русі (завдяки бездротовим технологіям).

5. Часова мобільність: процес навчання «розгортається» у часі, обумовлює поліхронічність та багатозадачність (розподіл робочого та особистого часу стає більш розмитим).

Впровадження M-learning в навчальний процес здійснюється за схемою: 1) вихідний, т. зв. «нульовий» аналіз потреб суб'єктів навчання відповідно до наявних навчальних досягнень (базується на самоаналізі SWOT - strengths, weaknesses, opportunities and threats); 2) підбір чи створення МД; 3) поточне оцінювання навчальних досягнень за умов використання мобільних додатків [6].

Р. Горбатюк та Ю. Тулашвілі [1] виділяють три основні напрямки впровадження M-learning у навчальних процес підготовки майбутніх фахівців з вищою освітою із застосуванням мобільних пристроїв:

І. Доступ до сайтів з навчальною інфрормацією (застосовується як одна з форм дистанційного навчання).

Першим і найпоширенішим способом є використання мобільного телефону як засобу доступу в глобальну мережу. Можлива організація доступу на спеціалізовані сайти, що містять електронні навчальні курси, тести, практичні завдання та додаткові навчальні матеріали (рисунки, фотографії, звукові та відео фрайли). Крім цього, можливий обмін електронною поштою в освітніх цілях і обмін терміновими повідомленнями в програмах ICQ, QIP, версії яких існують для мобільних телефонів. Таким чином, на всіх етапах навчання існує багато можливостей для передачі інформаційних матеріалів до суб'єктів навчання.

II. Відтворення звукових, текстових, відео і графрічних фрайлів, що містять навчальну інформацію. Використання спеціальних програм для платфрорм телефонів дозволяє відкривати та переглядати фрайли офрісних програм (Word, PowerPoint, Excel).

Таким чином, маючи в пам'яті мобільного телефону файли, що містять навчальну інформацію, можна переглядати їх версії, адаптовані спеціально для екрана телефону, із зручними смугами прокрутки, потрібним шрифртом і зручним інтерфейсом.

III Організація навчання з використанням адаптованих електронних підручників, навчальних курсів і файлів спеціалізованих типів з навчальною інформацією.

M-learning здатне забезпечити: 1) покращення сприйняття візуальної складової навчальної інформації, наприклад, онлайн-лекцій; 2) збільшення ефективності роботи користувачів шляхом синхронного навчання; 3) афективні фактори в навчанні за допомогою мобільних пристроїв (зростання зацікавленості та мотивації навчальної діяльності) [11].

Електронні засоби навчального призначення можуть сьогодні розроблятися безпосередньо для платформ мобільних телефонів. Студентам пропонується завантажити на телефон Java-додатки, що містять, наприклад, тести з певних предметів, а також інформацію (електронні підручники, тексти лекцій), необхідну для їх успішного виконання. Сучасні технології дозволяють спроектувати і програмно реалізувати такі електронні посібники. Можливість розміщення схем, креслень і фрормул робить написання електронних навчальних курсів для мобільних телефонів універсальним і абсолютно придатним для будь-якого досліджуваного предмета. Можлива реалізація навчальних програм в ігровій оболонці, використовуючи можливості графіки телефонів, проте - це складний і трудомісткий процес. Унаслідок цього, написання електронних підручників і програм предметного тестування для мобільних телефонів є сьогодні основним напрямком у M-learning $[14,15]$. 
Термін M-learning зводиться до використання мобільних і кишенькових IT-пристроїв, таких як персональний цифрровий помічник (PDA), мобільні телефони, ноутбуки і планшетні ПК, у викладанні й навчанні [3].

Мобільне навчання тісно пов'язано з таким підходом, як BYOD (Bring Your Own Device «приносьте власний прилад»). Аналогічною є абревіатура BYOT (Bring Your Own Technology). Дехто вважає ці терміни повністю ідентичними, інші використовують BYOD лише у випадку, коли учні/студенти приносять один із приладів зі складеного навчальним закладом списку, а ВҮОТ - у випадку, коли немає обмежень у приладах, що можуть бути використані [16].

Необхідною умовою застосування мобільних приладів є розробка продуманої політики, що може забезпечити цільове їх застосування. Умовою ефективності даної політики є забезпечення необхідної технічної підтримки та інфрраструктури, а також розробка методів оцінки її ефективності.

За відгуками викладачів, підхід BYOD дозволяє суттєво збільшити мотивацію, а також підвищити так звану мобільну грамотність, тобто уміння грамотно використовувати мобільні технології [17].

Медіаграмотність - складова медіакультури, яка стосується вміння користуватися інформаційнокомунікативною технікою, виражати себе і спілкуватися за допомогою медіазасобів, успішно здобувати необхідну інформацію, свідомо сприймати і критично тлумачити інформацію, отриману з різних медіа, відділяти реальність від ії віртуальної симуляції, тобто розуміти реальність, сконструйовану медіаджерелами, осмислювати владні стосунки, міфи і типи контролю, які вони культивують [18].

Типовими ознаками мобільного навчання є [3]:

- використання мобільних пристроїв (мобільні телефони, ноутбуки, КПК, планшети, електронні читачі «рідери» тощо);

- взаємодія учасників навчального процесу забезпечується і підтримується за допомогою бездротових мереж;

- навчання здійснюється незалежно від часу і місця знаходження його учасників;

- під час здійснення мобільного навчання створюється мобільне інформаційно-освітнє середовище.

Як зазначалося, мобільне навчання тісно пов'язане з електронним і дистанційним навчанням, так як особливістю його $є$ використання мобільних пристроїв. Навчання проходить незалежно від місця знаходження і відбувається з використанням портативних технологій. Іншими словами, мобільне навчання зменшує обмеження здобуття освіти щодо місцезнаходження за допомогою портативних пристроїв [3].

Визначальним фактором мобільного навчання $€$ використання портативних обчислювальних пристроїв разом із бездротовими мережами, що забезпечує можливість викладати і навчатися в будьякому місці за межами традиційної аудиторії [3]. Це будь-яка діяльність, яка дозволяє людям бути більш продуктивними шляхом взаємодії, або створення інформації, за допомогою цифрових портативних пристроїв, які можуть зберігатися в кишені або сумці. Апаратними пристроями для мобільного навчання можна назвати [3]:

- телефони: звичайні мобільні телефони, смартфони, комунікатори;

- портативні комп'ютери: ноутбуки, нетбуки, Інтернет планшети;

- пристрої зберігання і відтворення інформації: електронні «рідери» (Pocket Book, Amazom Kindle), MP3/MP4 плеєри.

\section{III Результати}

Мобільний додаток (МД) - це спеціальна програма, яка встановлюється користувачем на мобільний пристрій, як правило через ринки (портали, магазини, маркетплейси). Найпопулярніші AppStore, Google Play, де налічується уже мільярди МД з різним призначенням на будь-який смак: різні ігри та розваги, 3MІ, журнали, книги, соцмережі, гігантські торгові площадки, резервація готелів, замовлення доставки з ресторанів і кафе, мобільні версії служб знайомств, додатки погоди, курсу валют, цін на паливо де дешевше, медичні додатки, що відслідковують самопочуття хворих, доступ до банківських рахунків тощо. Мобільні додатки на відміну від сайтів переважно створюються під якусь 
конкретну платформу (IOS, Android, Windows Phone i т.д.) і називаються нативними [19]. Використання МД в освітньому процесі відноситься до Арр-моделі (від application - додаток) M-learnung.

Використання МД забезпечуються такими особливостями мобільного навчання [20]:

- можливість індивідуального використання при виконанні самостійної роботи;

- можливість використання при вирішенні навчальних проблемних ситуацій;

- доречний варіант у разі відсутності літератури;

- доступність для усіх користувачів мережі Інтернет.

У використанні мобільних додатків можливе як розважальне, так і практичне призначення. Серед МД другої групи можна виділити такі, які мають освітні можливості. Саме їх доречно використовувати у фаховій підготовці майбутніх вчителів біології.

Так як допомогою мобільного телефону можна одержати доступ до навчальних та довідкових ресурсів, то спеціалізоване програмне забезпечення здатне створити підтримку навчальної програми, особливо під час самостійної підготовки [16].

Зупинимось на основних перевагах та недоліках мобільного навчання (M-learning).

Основними перевагами застосування технології M-learning є:

1. Інноваційність технології.

2. Можливість використання переносних пристроїв з освітньою метою.

3. Можливість застосування технології в якості додаткового засобу навчання.

4. Підвищена ефективність у навчанні осіб з обмеженнями щодо здоров'я.

5. Можливість одночасної взаємодії з однією особою і з групою осіб.

6. Зручність, мобільність і гнучкість.

7. Відсутність обмежень за часом, місцем і розкладом навчання та відсутність вікових обмежень.

8. Персоналізація навчання.

9. Компактність.

До недоліків впровадження технології M-learning можна віднести:

1. Висока вартість технології для користувачів, т. зв. «ціновий бар'єр».

2. Несумісність деяких мобільних пристроїв з іншими програмами та пристроями.

3. Неможливість поєднання двох мереж різної архітектури.

4. Фрагментація навчання.

5. Обмежені розміри і ємність мобільних пристроїв.

6. Обмеження освітньої інфрормації з візуалізації.

7. Обмеження за швидкістю передачі інформації на мобільні пристрої.

8. Функціональні можливості мобільних пристроїв.

9. Обмежений термін роботи батареї мобільного пристрою.

10. Відсутність в учнів/студентів добре розвинених навичок самоконтролю та самокерування власною пізнавальною діяльністю.

11. Недостатня «технічна» підготовка викладачів у створені мобільного додатку $[1,2]$.

12. Відсутність, подекуди, якісного Інтернет покриття.

13. Велика кількість стандартів, розмірів екрану та операційних систем.

14. Погана представленість україномовного контенту.

\section{IV Обговорення}

Проаналізувавши представленість та перевіривши на практиці ряд мобільних додатків порталу Google Play, можна стверджувати, що ряд з них можна успішно використовувати під час організації навчальної діяльності зі студентами-біологами. Вони можуть бути доречними при вивченні видового складу рослин, опанування латинських термінів, вивчення особливостей практичного використання рослин та ін.

Розглянемо можливості використання мобільних додатків при викладанні навчальних дисциплін циклу фахової підготовки за спеціальністю 014.05 Середня освіта (Біологія та здоров'я людини). Великий обсяг МД можна умовно розподілити на п'ять основних функціональних груп (рис. 3). 


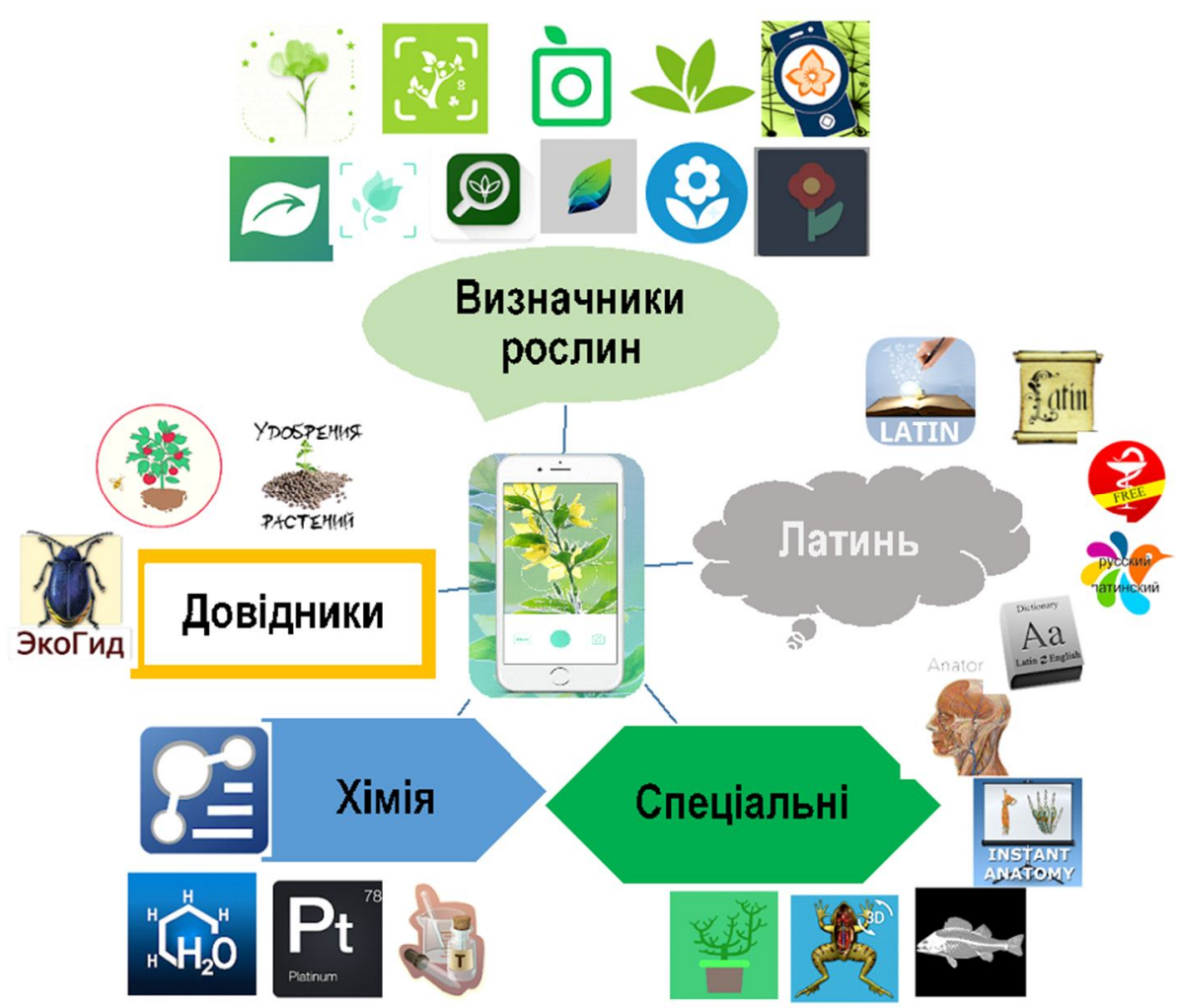

Рис. 3. Система мобільних додатків у підготовці майбутнього вчителя біології

І. Мобільні додатки 3 визначення видової належності рослин. Це велика група додатків, принцип роботи яких базується на аналізі фото основних вегетативних та генеративних частин рослини і порівнянні їх з наявною цифровою фотобазою. В деяких додатках $€$ можливість консультації 3 фахівцями-експертами.

Такі мобільні додатки мають як значні переваги, так і недоліки. Вагомими перевагами є широка доступність, економічність (більшість $€$ безкоштовними або умовно безкоштовними) та простота використання. Недоліки ж полягають у невідповідності та помилках у визначенні. Хоча, слід зауважити, що точність визначення належності до такосонів надвидового рангу (родини, роду) близько 90\%. До цієї групи додатків відносяться такі МД: PlantSnap - Identify Plants, Flowers, Trees \& More; Flowers, Trees \& More; Flora Incognita - automatische Pflanzenbestimmung; PictureThis - Flower \& Plant Identification; iNaturalist; PlantFinder - Flower \& Plant Identification; Plants Identification; Plant Identifier; FlowerChecker+, plant identify; Right Plants та ін.

Зазначені МД мають практичне значення з ідентифікації рослин і можуть бути використані під час лабораторного курсу з «Ботаніки з основами геоботаніки», «Вступу до фаху»; під час екскурсій в природу; виконання індивідуальних дослідних завдань, виконання кваліфікаційних робіт, самостійної роботи, а також під час навчально-польової практики. Використання даних МД значно економить час на визначення належності рослини до надвидових таксонів, але потребує уточнення видової належності за ключем визначника.

II. Мобільні додатки довідкового характеру можуть бути корисними при проведенні морфологічного опису рослин, виявленні особливостей їх хімічного складу та використанні у медицині, веденні господарської діяльності (рослинництво, садівництво, плодівництво тощо). Їх використання доцільне при опануванні таких навчальних дисциплін, як «Основи сільського господарства», «Лікарські рослини», «Основи екології», «Генетика з основами селекції» для вивчення морфології та екології рослин, практичного застосування у фітотерапії. До цієї групи можна віднести такі МД: Все про рослини (кімнатні та садові); Комнатные растения и цветы: справочник по уходу; Домашние Цветы; Травник. Часть1; Цветочный помощник; Комнатные растения и цветы: справочник по уходу; Справочник лекарственных трав и ядовитых растений; Справочник растений; ЭкоГид: Цветы; Вредители и болезни 
растений; Що це за квітка?; Менеджер Комнатных Растений; Мобильный садовник. Определитель болезней растений; Плодовые деревья; Лікарські трави та ін.

III. Мобільні додатки з латинської мови, що можуть бути корисні в опануванні біологічних термінів латинського походження. Вони стануть у нагоді при вивченні навчальних дисциплін циклу фахової підготовки майбутніх вчителів біології, а саме: «Ботаніка з основами геоботаніки», «Зоологія безхребетних та хребетних», «Мікробіологія та вірусологія», «Основи екології», «Анатомія людини» та ін. 3 метою опанування біологічної терміносистеми, створення біологічного термінологічного словника, опанування семантики та етимології біологічних терміноелементів можуть бути використані такі МД: Основы Латинского языка; Латинско-русский и русско-латинский словарь; Latin. A collection of catch phrases; Медицинские словари (Русско - Латинские); Learn\&Read Latin Words\&Phrases; Latin - English; Sriba Latin dictionary та ін.

IV. Вузькоспеціальні мобільні додатки, які сприяють унаочненню певних особливостей будови чи функціонування біологічних систем. Це такі МД: Физиология человека; Нормальная анатомия человека; Нормальная физиология FREE; Internal Organs in 3D (Anatomy); Метаболізм; Anatomy 3D Atlas; Нейрофізіологія; Anatomy \& Physiology 2019; Classic Anatomy; Витамины в продуктах питания та ін. Такі МД стануть у нагоді при опануванні навчальних дисциплін «Анатомія людини», «Фізіологія рослин», «Цитологія та гістологія» та ін.

V. Мобільні додатки з хімії можуть бути корисними при вивченні та закріпленні знань з хімічного складу клітин, перебігу метаболічних процесів в організмі аеробів та анаеробів при опануванні навчальних дисциплін циклу фахової підготовки майбутнього вчителя біології «Фізіологія рослин», «Анатомія людини», «Ботаніка з основами геоботаніки», «Зоологія», «Мікробіологія та вірусологія» та ін.

\section{V Висновки}

Технологія M-learning відрізняється мобільністю та гнучкістю, створює умови для покращення продуктивності навчання, доцільна при організації навчального процесу не тільки під час лабораторнопрактичних занять, а також і в зручний час для суб'єктів навчання.

Визначення «мобільне» визначає дві складові педагогічного процесу: доступ до навчальної інформації та форми реалізації навчальної взаємодії. M-learning здійснюється у особливому сучасному інформаційно-освітньому середовищі, дидактичними характеристиками якого $є$ висока швидкість створення, обробки й передавання інформації, двосторонній характер комунікацій, можливість роботи 3 гіпертекстом і мультимедією, відкритий доступ до інформаційних ресурсів.

Використання мобільних додатків є однією із моделей мобільного навчання, так звана Аррмодель M-learning. На основі аналізу представленості та практичній перевірці наявних МД порталу Google Play їx можна розподілити на п'ять основних функціональних груп. Це велика група МД 3 визначення видової належності рослин, довідкового характеру, з латинської мови, вузькоспеціальні та МД з хімії. Усі вони стануть у нагоді в організації навчальної діяльності майбутніх вчителів біології.

Перспективними напрямками подальших досліджень можна вважати проблему створення мобільних додатків, призначених для активізації навчально-дослідницької діяльності під час фахової підготовки майбутніх вчителів біології.

\section{Бібліографічні посилання}

1. Горбатюк Р. М., Тулашвілі Ю. Й.. Мобільне навчання як нова технологія вищої освіти / Науковий вісник Ужгородського національного університету. 2013.№27. С. 31-34. URL: http://nbuv.gov.ua/UJRN/ Nvuuped_2013_27_10 (дата звернення 27.07.2019).

2. Пэйн H. 10 элементов мобильного обучения. Дистанционное обучение: информационный портал. URL: http://www.distance-learning.ru/db/el/C89AA03833448937C32577660010ACF1/doc.html (дата звернення 27.07.2019).

3. Бугайчук К. Л. Мобільне навчання: сутність і моделі впровадження в навчальний процес вищих навчальних закладів MBC України / Інформаційні технології і засоби навчання. 2012. № 1 (27). URL: http: // journal.iitta. gov.ua /index.php litlt article /view /619 /480 (дата звернення 27.07.2019).

4. Семеріков С. О. Фундаменталізація навчання інформатичних дисциплін у вищій школі : монографрія. К.: НПУ ім. М. П. Драгоманова, 2009. 340 c. URL: http://lib.iitta.gov.ua/704142/1/9789667830113_content.pdf (дата звернення 27.07.2019). 
5. Скрипка Г. В. Використання мобільних додатків для проведення навчальних досліджень під час вивчення предметів природничо-математичного циклу / Комп'ютер у школі та сім'ї. 2015. № 3. С. 28-31. URL: http://nbuv.gov.ua/UJRN/ komp_2015_3_8 (дата звернення 27.07.2019).

6. Klimova B. Impact of Mobile Learning on Students' Achievement Results. Edication Sciences. 2019. DOI: 10.3390/educsci9020090.

7. Pachler N., Bachmair B., Cook J. Cases of Mobile Learning. In: Mobile Learning. Springer, Boston, MA. 2010. P.73-93. DOI: 10.1007/978-1-4419-0585-7_2 URL: https://link.springer.com/chapter/10.1007/978-1-4419-0585-7_2 (дата звернення 27.07.2019).

8. Pachler N., Cook J., Bachmair B., Rummler K. Mobile learning: Structures, agency, practices. 2010. DOI: 10.1007/978-14419-0585-7.

9. Cowan P., Butler R. Using Activity Theory to Problematize the Role of the Teacher During Mobile Learning / SAGE Open. 2013. DOI: $10.1177 / 2158244013516155$.

10. Pedro L., Barbosa C., Santos C. A critical review of mobile learning integration in formal educational contexts / International Journal of Educational Technology in Higher Education. 15:10. 2010. DOI: 10.1186/s41239-018-0091-4.

11. Shen R. Constructing a user experience-based mobile learning environment: Problems and solutions. FernUniversität, Hagen, Germany. 2012. URL: https://pdfs.semanticscholar.org/270d/07ba2e94cdedfe9b90a52eb8b85622febf9c.pdf (дата звернення 27.07.2019).

12. Gikas J., Grant M. Mobile computing devices in higher education: Student perspectives on learning with cellphones, smartphones \& social media / The Internet and Higher Education. Volume 19. 2013. P. 18-26. DOI: $10.1016 /$ J.IHEDUC.2013.06.002.

13. Saccol A., Reinhard N., Schlemmer E., Barbosa J. M-learning (Mobile learning) in Practice: a Training Experience With it Professionals / JISTEM - Journal of Information Systems and Technology Management. Vol.7, no.2. São Paulo, 2010. DOI: $110.4301 / \mathrm{S} 1807-17752010000200002$.

14. Crompton H., Burke D. The use of mobile learning in higher education: A systematic review / Computers \& Education. Volume 123, 2018, P. 53-64. DOI: 10.1016/j.compedu.2018.04.007.

15. Martin F., Ertzberger J. Here and now mobile learning: An experimental study on the use of mobile technology / Computers \& Education. Volume 68, 2013, P.76-85. DOI: 10.1016/j.compedu.2013.04.021.

16. Білоус В. В. Мобільні додатки для навчання математики як засіб підвищення мотивації учнів молодшої школи / Відкрите освітнє е-середовище сучасного університету. 2017. № 3. С. 303-309.

17. Евзикова О. В. Что такое мобильное обучение и BYOD / Teachtech. 2015. URL: http://teachtech.ru/teoriya-onlajnobucheniya/chto-takoemobilnoe-obuchenie-i-byod.html (дата звернення 27.07.2019).

18. Концепція впровадження медіа-освіти в Україні. URL: https://ms.detector.media/ mediaprosvita/ mediaosvita/ kontseptsiya_vprovadzhennya_mediaosviti_v_ukraini_nova_redaktsiya/ (дата звернення 27.07.2019).

19. Голицына И. Н., Половникова Н. Л. Мобильное обучение как новая технология в образовании / Образовательные технологии и общество. 2011. №1. Том 14. С. 241-252. URL: https://cyberleninka.ru/article/n/mobilnoe-obuchenie-kaknovaya-tehnologiya-v-obrazovanii (дата звернення 27.07.2019).

20. Квасніцька Н. І. Застосування мобільних технологій на уроках математики / ХІІІ Хмурівські читання - кафедра ТімСО. URL: $\quad$ http://timso.koippo.kr.ua/hmura13/kvasnitska-natalya-ivanivna-zastosuvannya-mobilnyh-tehnolohij-na-urokahmatematyky (дата звернення 27.07.2019).

\section{References}

1. Horbatiuk, R. M., Tulashvili, Yu. Y. (2013). Mobilne navchannia yak nova tekhnolohiia vyshchoi osvity. [Mobile learning as a new technology of higher education]. Scientific Bulletin of Uzhgorod National University, 27, 31-34. URL: http://nbuv.gov.ua/UJRN/ Nvuuped_2013_27_10 (accessed 27.07.2019). [in Ukranian].

2. Peyn, N. (2015). 10 elementov mobilnogo obucheniya. [10 elements of mobile learning]. Distance Learning: Information Portal. URL: http://www.distance-learning.ru/db/el/C89AA03833448937C32577660010ACF1/doc.html (accessed 27.07.2019). [in Russian].

3. Buhaichuk, K. L. (2012). Mobilne navchannia: sutnist i modeli vprovadzhennia v navchalnyi protses vyshchykh navchalnykh zakladiv MVS Ukrainy [Mobile Learning: The Essence and Models of Implementation of Higher Education Institutions in the Ministry of Internal Affairs of Ukraine]. Information technology and training tools, 1(27). URL: http: // journal.ïtta. gov.ua /index.php /ittl article /view /619/480 (accessed 27.07.2019). [in Ukranian].

4. Semerikov, S. O. (2009). Fundamentalizatsiia navchannia informatychnykh dystsyplin u vyshchii shkoli [Fundamentalisation of higher education education in computer science]: monograph. NPDU, Kyiv, Ukraine, $340 . \quad$ URL: http://lib.iitta.gov.ua/704142/1/9789667830113_content.pdf (accessed 27.07.2019). [in Ukranian].

5. Skrypka, H. V. (2015). Vykorystannia mobilnykh dodatkiv dlia provedennia navchalnykh doslidzhen pid chas vyvchennia predmetiv pryrodnycho-matematychnoho tsyklu [Use of mobile applications for educational research in the study of subjects of the natural and mathematical cycle]. Computer at school and family, 3, 28-31. URL: http://nbuv.gov.ua/UJRN/komp_2015_3_8 (accessed 27.07.2019). [in Ukranian].

6. Klimova, B. (2019). Impact of Mobile Learning on Students' Achievement Results. Edication Sciences. DOI: 10.3390/educsci9020090

7. Pachler, N., Bachmair, B., Cook, J. (2010). Cases of Mobile Learning. In: Mobile Learning. Springer, Boston, MA. P.73-93. DOI: 10.1007/978-1-4419-0585-7_2 
8. Pachler, N., Cook, J., Bachmair, B., Rummler, K. (2010). Mobile learning: Structures, agency, practices. DOI: 10.1007/9781-4419-0585-7

9. Cowan, P., Butler, R. (2013). Using Activity Theory to Problematize the Role of the Teacher During Mobile Learning. SAGE Open. DOI: $10.1177 / 2158244013516155$

10. Pedro, L., Barbosa, C., Santos, C. (2018). A critical review of mobile learning integration in formal educational contexts. International Journal of Educational Technology in Higher Education. 15:10. DOI 10.1186/s41239-018-0091-4

11. Shen, R. (2012). Constructing a user experience-based mobile learning environment: Problems and solutions. FernUniversität, $\quad$ Hagen, Germany. URL: https://pdfs.semanticscholar.org/270d/07ba2e94cdedfe9b90a52eb8b85622febf9c. pdf (accessed 27.07.2019).

12. Gikas, J., Grant, M. (2013). Mobile computing devices in higher education: Student perspectives on learning with cellphones, smartphones \& social media. The Internet and Higher Education. Volume 19, 2013, P.18-26. DOI: 10.1016/J.IHEDUC.2013.06.002 [

13. Saccol, A., Reinhard, N., Schlemmer, E., Barbosa, J. (2010). M-learning (Mobile learning) in Practice: a Training Experience With it Professionals JISTEM - Journal of Information Systems and Technology Management. Vol.7, no.2. São Paulo, 2010. DOI: $110.4301 / \mathrm{S} 1807-17752010000200002$

14. Crompton, H., Burke, D. (2018). The use of mobile learning in higher education: A systematic review. Computers \& Education. Volume 123, P. 53-64. DOI: 10.1016/j.compedu.2018.04.007

15. Martin, F., Ertzberger, J. (2013). Here and now mobile learning: An experimental study on the use of mobile technology. Computers \& Education. Volume 68, 2013, P.76-85. DOI: 10.1016/j.compedu.2013.04.021

16. Bilous, V. V. (2017). Mobilni dodatky dlia navchannia matematyky yak zasib pidvyshchennia motyvatsii uchniv molodshoi shkoly [Mobile applications for teaching mathematics as a means of enhancing the motivation of elementary school students]. The open e-learning environment of the modern university, 3, 303-309. [in Ukranian].

17. Evzikova, O. V. (2015). Chto takoye mobilnoye obucheniye i BYOD. [What is mobile learning and BYOD]. Teachtech. URL: http://teachtech.ru/teoriya-onlajn-obucheniya/chto-takoemobilnoe-obuchenie-i-byod.html (accessed 27.07.2019). [in Russian].

18. Kontseptsiia vprovadzhennia media-osvity $v$ Ukraini [Concept of introduction of media education in Ukraine]. URL: https://ms.detector.media/mediaprosvita/mediaosvita/kontseptsiya_vprovadzhennya_mediaosviti_v_ukraini_nova_redaktsiya I (accessed 27.07.2019). [in Ukranian].

19. Golitsyna, I. N.. Polovnikova, N. L. (2011). Mobilnoye obucheniye kak novaya tekhnologiya v obrazovanii. [Mobile learning as a new technology in education]. Educational technologies and society, 1, 14, 241-252. URL: https://cyberleninka.ru/article/n/mobilnoe-obuchenie-kak-novaya-tehnologiya-v-obrazovanii (accessed 27.07.2019). [in Russian].

20. Kvasnitska, N. I. (2013). Zastosuvannia mobilnykh tekhnolohii na urokakh matematyky [Application of mobile technologies in mathematics lessons]. XIII Khmur Readings - TiMSO Department. URL: http://timso.koippo.kr.ua/hmura13/kvasnitskanatalya-ivanivna-zastosuvannya-mobilnyh-tehnolohij-na-urokah-matematyky/ (accessed 27.07.2019). [in Ukranian].

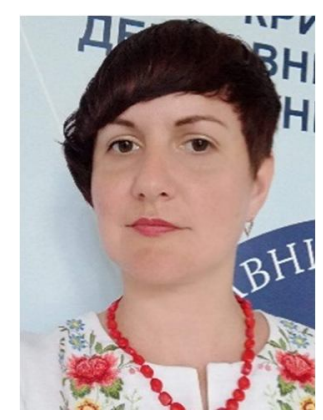

Перерва Вікторія Вікторівна.

Асистент кафедри ботаніки та екології, Криворізький державний педагогічний університет проспект Гагаріна, 54, м. Кривий Ріг, Україна, 50086.

Тел: +38(097)512-98-91. E-mail: pererva@kdpu.edu.ua

\section{Pererva Victoria Victorivna.}

Assistant of Biology and Ecology Department, Kryvyi Rih State Pedagogical University.

Gagaryn Avenue, 54, Kryvyi Rih, Ukraine, 50086.

Phone: +38(097)512-98-91. E-mail: pererva@kdpu.edu.ua

ORCID: 0000-0002-7086-3050

Researcher ID: E-7602-2019

\section{Citation (APA):}

Pererva, V. V. (2019). Professional training of a future biology teacher using M-learning technology. Engineering and Educational Technologies, 7 (3), 75-84. doi: https://doi.org/10.30929/2307-9770.2019.07.03.07

\section{Цитування (ДСТУ 8302:2015):}

Перерва В. В. Фахова підготовка майбутнього вчителя біології з використанням технології M-learning / Інженерні та освітні технології. 2019. Т. 7. № 3. С. 75-84. doi: https://doi.org/10.30929/2307-9770.2019.07.03.07

Обсяг статmi: $\quad$ сторінок-10 ; умовних друк. аркушів - 1,448. 